\title{
URBANIZAÇÃO E EXPANSÃO DO CIRCUITO INFERIOR DA ECONOMIA URBANA NO TERRITÓRIO POTIGUAR E NO EIXO RODOVIÁRIO NATAL-CAICÓ
}

\author{
URBANIZATION AND EXPANSION IN LOWER CIRCUIT OF THE URBAN ECONOMY IN POTIGUAR TERRITORY AND IN \\ ROAD AXIS NATAL-CAICÓ
}

\section{RESUMO}

Neste artigo, analisamos a atual dinâmica econômica, a urbanização e a expansão do circuito inferior da economia urbana no Rio Grande do Norte e, especificamente, no eixo rodoviário Natal-Caicó. Adotamos esse eixo rodoviário como recorte de análise devido ao fato desse subsistema de movimentos do território potiguar interligar municípios do interior e do litoral do estado, se destacar pelos fluxos intermunicipais de passageiros e se caracterizar por cidades cujo centro econômico importante é a rodovia que as atravessa, sendo a rodovia margeada, sobretudo, por diversas atividades da economia não hegemônica. A análise que fazemos é fundamentada em reflexões teóricas sobre a dinâmica socioeconômica do território potiguar e na interpretação de dados estatísticos referentes à essa dinâmica e de dados primários decorrentes de pesquisa de campo realizada no eixo Natal-Caicó. Destarte, refletimos sobre a modernização econômica do território potiguar, atentando para o processo de urbanização desse território e do eixo rodoviário Natal-Caicó e apreendemos a contribuição da expansão da economia não hegemônica para o referido processo de urbanização. Concluímos considerando que as cidades e a economia crescem alicerçadas, sobretudo, em atividades econômicas mantenedoras da pobreza estrutural produzida pela modernização do território, situação essa característica do processo de precarização do trabalho. Como resposta sistêmica a essa situação, tem-se a segmentação da economia urbana, com o subsistema inferior cada vez mais dependente do superior, assim como mais permanente e receptor de trabalhadores diante da precarização das relações de trabalho e do desemprego, hoje, duradouro.

Palavras-chave: Dinâmica econômica. Urbanização. Circuito inferior da economia urbana. Rio Grande do Norte. Eixo rodoviário Natal-Caicó.

\section{ABSTRACT}

In this article, we analyze the current economic dynamics, the urbanization and the expansion of the lower circuit of the urban economy in Rio Grande do Norte and, specifically, on the road axis Natal-Caicó. We have adopted this road as cutting analysis due to the fact that subsystem of potiguar territory connect municipalities of the interior and the coast of the State, stand out by intercity passenger flows and be characterized by cities whose economic center is the highway that passes through, being the highway bordered by various activities of the economy not hegemonic. Our analysis is grounded in theoretical reflections on the socioeconomic dynamics of the potiguar territory and in the interpretation of statistical data regarding this dynamic and primary data resulting from field research conducted on axis Natal-Caicó. Thus, we reflect on the economic modernization of the potiguar territory, paying attention to the process of urbanization of that territory and the road axis Natal-Caicó and understated the contribution of expansion of not hegemonic economy to the process of urbanization. We conclude whereas the cities and the economy grow based on supporters of poverty structural economic activities produced by the modernization of the territory, this characteristic of the process of precarious work. As systemic response to this situation, there is the threading of the urban economy, with the lower subsystem increasingly dependent on top, as well as more permanent and receiver of workers with precarious work relations and unemployment.

Keywords: Economic dynamics. Urbanization. Lower circuit of the urban economy. Rio Grande do Norte. Road axis Natal-Caicó.
Diego Salomão Candido de Oliveira Salvador $^{\text {a }}$

${ }^{\text {a }}$ Universidade Federal do Rio Grande do Norte (UFRN), Natal, RN, Brasil

DOI: $10.12957 /$ geouerj.2020.29771

Correpondência: diegosalomao84@hotmail.com

Recebido em: 27 jul. 2017

Revisado em: 17 set. 2019

Aceito em: 7 jan. 2020 


\section{INTRODUÇÃO}

No Rio Grande do Norte existem quatro eixos rodoviários que macroestruturam o território (figura 1): o Natal-Fronteira Paraibana, utilizado para o transporte de passageiros e para o escoamento de balas, chapas plásticas, tecidos de algodão, granito, tungstênio e açúcar, em direção ao Porto de Suape e a Recife; o NatalMacau, com utilização para transporte de passageiros e de carga de materiais de construção (brita, cal), combustível para aviação e automóveis bem como equipamentos para parque eólico; o Natal-Mossoró, utilizado para transporte de passageiros e de carga de frutas, castanha de caju, tecidos de algodão, produtos animais impróprios para alimentação humana, lagosta, peixes, camarão, tungstênio e balas, em direção ao Porto de Pecém, a Fortaleza e a Natal, e de sal, para abastecimento do mercado estadual ou regional, sendo que, para o escoamento desse produto, há uma importante conexão do eixo Natal-Mossoró com o Porto de Areia Branca; e o Natal-Caicó, com utilização, sobretudo, para o fluxo de passageiros, contudo também evidenciando o transporte de carga de produtos têxteis e alimentícios em pequena quantidade.

Figura 1. Eixos rodoviários que macroestruturam o território potiguar. Organização: Diego Salomão C. O. Salvador, 2013. Cartografia: Robson Garcia da Silva, 2013.
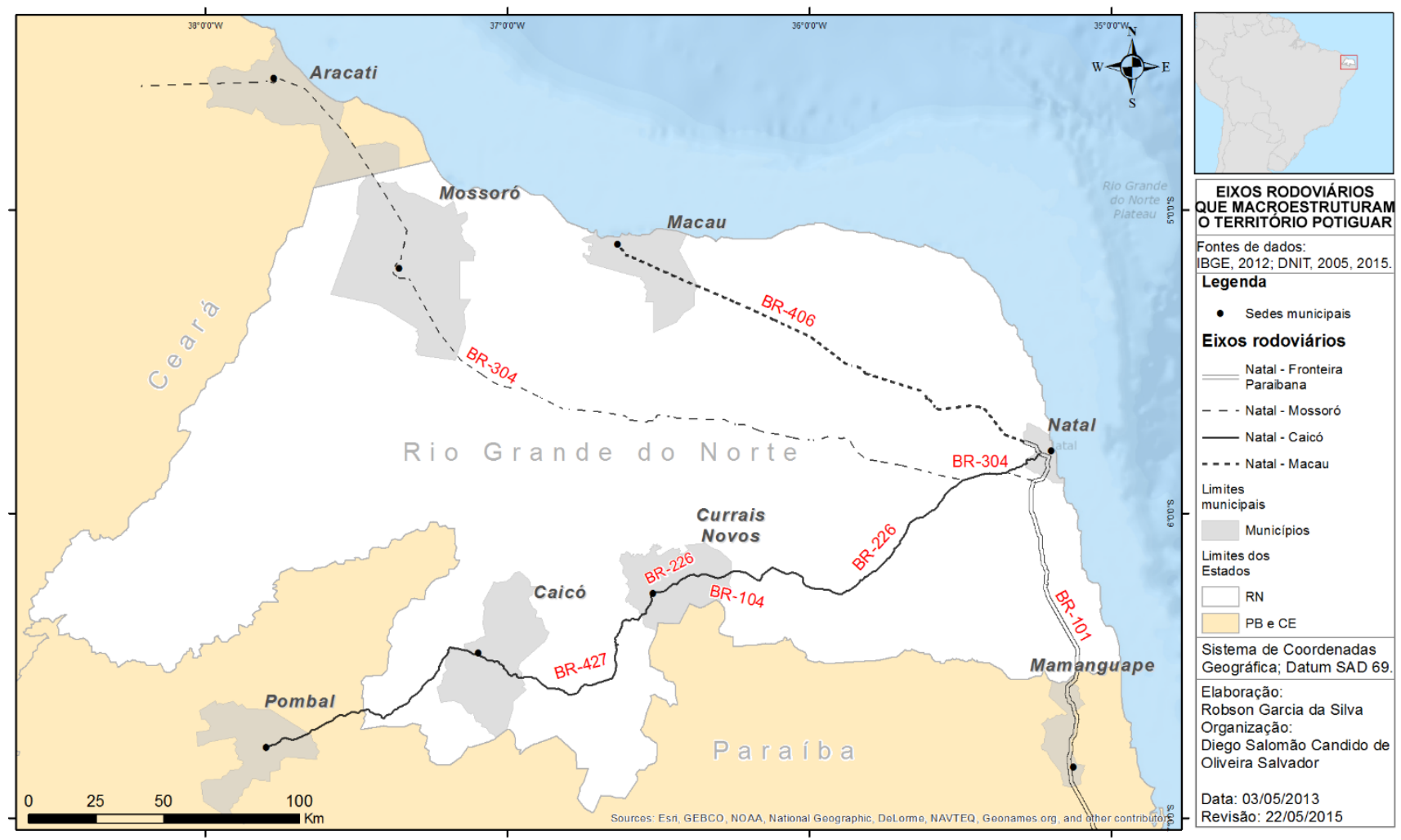
Neste artigo, analisamos a atual dinâmica econômica, a urbanização e a expansão do circuito inferior da economia urbana ${ }^{1}$ no Rio Grande do Norte e, especificamente, no eixo rodoviário Natal-Caicó. Adotamos esse eixo rodoviário como recorte de análise devido ao fato desse subsistema de movimentos do território potiguar interligar municípios do interior e do litoral do estado, se destacar pelos fluxos intermunicipais de passageiros e se caracterizar por cidades cujo centro econômico importante é a rodovia que as atravessa, sendo a rodovia margeada, sobretudo, por diversas atividades da economia não hegemônica.

A análise que fazemos é fundamentada em reflexões teóricas sobre a dinâmica socioeconômica do território potiguar e na interpretação de dados estatísticos referentes à essa dinâmica e de dados primários decorrentes de pesquisa de campo realizada no eixo rodoviário Natal-Caicó ${ }^{2}$. Essa pesquisa foi realizada entre os meses de agosto de 2013 e janeiro de 2014, quando aplicamos questionário com 148 responsáveis por atividades não hegemônicas, cujos dados nos possibilitam refletir sobre a contribuição desse circuito para a urbanização do estado e, especificamente, do eixo rodoviário Natal-Caicó.

Destarte, refletimos sobre a modernização econômica do território potiguar, atentando para o processo de urbanização desse território e do eixo rodoviário Natal-Caicó. Após essa reflexão, concluímos, apreendendo a contribuição da expansão da economia não hegemônica para o referido processo de urbanização.

\section{A seletividade territorial do processo de modernização econômica do Rio Grande do Norte}

A dinâmica atual do território potiguar atrela-se ao processo de modernização econômica, intensificado desde a segunda metade do século XX. Tal processo vem ocorrendo de maneira seletiva e concentradora, privilegiando determinadas regiões, cidades, circuitos econômicos e agentes sociais na implementação de políticas que infraestruturam quantitativa e qualitativamente o território e, assim, possibilitam ações vantajosas. Nesse sentido, os sistemas de objetos e de ações do território norte-rio-grandense estão sob o

\footnotetext{
${ }^{1}$ Conforme a teoria dos circuitos da economia urbana dos países subdesenvolvidos (SANTOS, 1978), a dinâmica econômica da cidade desses países é segmentada em dois circuitos: circuito superior e circuito inferior. Tais circuitos coexistem no território, por meio de relações de concorrência, de complementaridade e de subordinação do circuito inferior ao circuito superior.

Os circuitos da economia urbana são definidos pelos níveis de capital, de tecnologia e de organização das suas atividades, bem como pelas suas escalas de atuação. O circuito superior da economia urbana do eixo rodoviário Natal-Caicó é definido por atividades de organização burocrática, considerável nível tecnológico e forte necessidade de capital para seu desenvolvimento, como bancos, indústria, comércio e serviços modernos, e atacadistas. Tais atividades têm ampla escala de atuação, relacionando-se com os âmbitos regional, nacional e até mesmo global. Já o circuito inferior desse eixo rodoviário é integrado por atividades de organização criativa e pouco ou nada burocrática, de tecnologia utilizada em nível inferior ao que ocorre naquele circuito e de menor necessidade de capital para o funcionamento, sendo, em contrapartida, imprescindível a intensidade de trabalho. É o caso das pequenas produções de alimentos, do pequeno comércio e dos serviços diversos fornecidos a varejo. As atividades não hegemônicas vêm, ultimamente, expandindo sua escala de atuação, contudo as relações com o lugar continuam importantes.

${ }^{2}$ As cidades que constituem o eixo rodoviário Natal-Caicó são: Natal (capital estadual), Parnamirim e Macaíba (cidades da Região Metropolitana de Natal), Caicó, Currais Novos e Santa Cruz (centros regionais sertanejos), e Bom Jesus, Senador Elói de Souza, Serra Caiada, Tangará, Campo Redondo, Acari e Jardim do Seridó (centros locais).
} 
comando de interesses hegemônicos que se beneficiam da desigual divisão territorial do trabalho ${ }^{3}$, fazendo-a perdurar.

Entendemos a modernização econômica como um processo de difusão espacial de variáveis-chave do período atual (técnica, ciência, informação, finanças, consumo), que assume proporções e intensidades diferentes e desiguais. Tal difusão, apoiada pelo Estado, privilegia os lugares mais aptos, do território nacional, regional ou estadual, para a implantação de novas infraestruturas e atividades que atendam as demandas de agentes hegemônicos do mercado.

Desse modo, o Rio Grande do Norte, assim como todo o território nacional, é um espaço cuja dinâmica é caracterizada por regiões e atividades mais afeitas à divisão internacional do trabalho e por regiões e atividades rarefeitas, quanto a fixos e fluxos hegemônicos.

Um dado importante para se conhecer as cidades e regiões luminosas de dado território é o consumo de energia elétrica. No território potiguar, de acordo com Araújo (2013), em 2010, no que tange ao consumo geral de energia elétrica, destacavam-se, respectivamente, as regiões de Natal, Mossoró, Macau-Guamaré, Assu, Pau dos Ferros e Seridó (Caicó e Currais Novos). No que se refere ao consumo comercial de energia elétrica por município, o destaque ficou para Natal, Mossoró, Caicó, Açu, Currais Novos e Pau dos Ferros. E ao consumo industrial de energia elétrica, o destaque foi das regiões de Natal, Mossoró e Macau-Guamaré.

Além disso, ao privilegiarem determinados lugares e atividades, as ações estatais também evidenciam quais são as principais regiões e economias do território planejado e ordenado. Os planos de desenvolvimento do Rio Grande do Norte vêm, nas últimas décadas, focando determinados circuitos econômicos hegemônicos voltados, sobretudo, ao mercado externo, como o do turismo, desenvolvido no litoral oriental; o das frutas irrigadas, desencadeado no Vale do Açu e na região de Mossoró; o dos crustáceos e peixes, localizado no litoral oriental e no Vale do Açu; e o do petróleo e do sal, desenvolvido na região de Macau-Guamaré e na de Mossoró (ARAÚJO, 2013). Esses planos evidenciam, de maneira explícita, o pacto firmado entre agentes hegemônicos da economia e da política, fato que torna o planejamento e o ordenamento do território mercadológicos.

Diante da seletividade territorial do processo de modernização econômica, podemos destacar, juntamente com Gomes (2009), que as regiões hegemônicas do Rio Grande do Norte são: Natal, Mossoró, Macau-Guamaré e Vale do Açu, por se inserirem, com certas densidades, nas dinâmicas da Globalização; e o Seridó, pela valorização de seu caráter histórico e cultural e pela modernização de seus potenciais econômicos.

\footnotetext{
${ }^{3}$ Remetendo às concepções de Durkheim ([1930] 1999) e de Santos ([1996] 2008), sublinhamos que a divisão do trabalho é a fonte eminente das solidariedades organizacional e orgânica. Compreendendo a divisão do trabalho, temos condições de apreender as situações dos agentes na sociedade bem como as forças hegemônicas e não hegemônicas que usam o território. Assim, podemos desvendar as desigualdades, as contradições e as combinações que caracterizam a divisão "territorial" do trabalho.
} 
Contudo, o território não é caracterizado apenas pelas regiões luminosas e pelos circuitos econômicos hegemônicos. Além das regiões ganhadoras e das empresas com alto nível de tecnologia, capital e organização burocrática, existem aquelas não privilegiadas pelas forças mais potentes da divisão territorial do trabalho bem como as atividades calcadas na intensidade do trabalho e na organização criativa, as quais empregam ou ocupam a maioria dos trabalhadores pobres. Em outras palavras, a totalidade da dinâmica territorial explicita diferentes e desiguais usos do sistema de objetos e intencionalidades quanto ao sistema de ações.

\section{A atual dinâmica econômica do Rio Grande do Norte}

Traçando um perfil da totalidade da dinâmica do Rio Grande do Norte, a Secretaria de Estado do Planejamento e das Finanças (SEPLAN), em 2014, destacou as grandes regiões do território potiguar e suas respectivas atividades econômicas, conforme evidenciado na tabela a seguir.

Tabela 1. Grandes regiões do território potiguar e respectivas atividades econômicas. Fonte: SEPLAN, Perfil do Rio Grande do Norte, 2014.

\begin{tabular}{|c|c|}
\hline Regiões & Atividades econômicas desencadeadas \\
\hline $\begin{array}{l}\text { Litoral Oriental } \\
\text { (Região de Natal) }\end{array}$ & $\begin{array}{l}\text { Turismo, cultivo de cana-de-açúcar, carcinicultura, floricultura, pecuária leiteira, cultivo de mandioca, } \\
\text { avicultura, fruticultura irrigada, cultura de caju, indústria de tecidos, indústria de confecções, indústria de } \\
\text { bebidas, indústria de álcool, indústria de açúcar, indústria de movelaria, construção civil, indústria ceramista, } \\
\text { indústria de farinha de mandioca, exploração mineral (água mineral, argila), comércio varejista, comércio } \\
\text { atacadista, prestação de serviços educacionais, prestação de serviços de saúde. }\end{array}$ \\
\hline $\begin{array}{l}\text { Região de } \\
\text { Mossoró }\end{array}$ & $\begin{array}{l}\text { Turismo, fruticultura irrigada (melão, manga, melancia), cultivo de caju, caprinocultura, ovinocultura, } \\
\text { apicultura, cultivo de milho e feijão, pecuária leiteira, indústria de cimento, indústria de movelaria, indústria } \\
\text { química, indústria de confecções, indústria de tecidos, indústria de calçados, indústria de castanha de caju, } \\
\text { indústria de rações, indústria mecânica, indústria de cerâmica fina, atividade salineira, exploração mineral } \\
\text { (calcário, água mineral), atividade petrolífera, comércio varejista e atacadista, prestação de serviços } \\
\text { educacionais, prestação de serviços de saúde. }\end{array}$ \\
\hline Região do Seridó & $\begin{array}{l}\text { Turismo, pecuária leiteira e de corte, piscicultura, cultivo de caju, caprinocultura, indústria de confecções, } \\
\text { indústria ceramista, indústria de laticínios, indústria artesanal, exploração mineral (feldspato, caulim, ferro, } \\
\text { tungstênio), comércio varejista e atacadista, prestação de serviços educacionais, prestação de serviços de } \\
\text { saúde. }\end{array}$ \\
\hline $\begin{array}{l}\text { Litoral Norte } \\
\text { (Região de Macau- } \\
\text { Guamaré) }\end{array}$ & $\begin{array}{l}\text { Turismo, caprinocultura, ovinocultura, pecuária leiteira, apicultura, cultivo de abacaxi, sisal, indústria de } \\
\text { laticínios, atividade petrolífera, atividade salineira, exploração mineral (calcário, ouro), comércio varejista, } \\
\text { prestação de serviços educacionais, prestação de serviços de saúde. }\end{array}$ \\
\hline Vale do Açu & $\begin{array}{l}\text { Turismo, fruticultura irrigada (melão, manga, melancia, banana), piscicultura, carcinicultura, indústria } \\
\text { ceramista, indústria de laticínios, indústria de mármore, atividade salineira, atividade petrolífera, exploração } \\
\text { mineral (calcário, argila), comércio varejista, prestação de serviços educacionais, prestação de serviços de } \\
\text { saúde. }\end{array}$ \\
\hline $\begin{array}{l}\text { Alto Oeste (Região } \\
\text { de Pau dos Ferros) }\end{array}$ & $\begin{array}{l}\text { Turismo, cultivo de arroz, feijão, fava e milho, suinocultura, cultivo de caju, caprinocultura, apicultura, } \\
\text { indústria de castanha de caju, indústria de doces, indústria de confecções, indústria de carroceria para } \\
\text { caminhão, comércio varejista, prestação de serviços educacionais, prestação de serviços de saúde. }\end{array}$ \\
\hline Região Agreste & $\begin{array}{l}\text { Pecuária leiteira, cultivo de feijão e milho, cultivo de abacaxi, caprinocultura, ovinocultura, cultivo da } \\
\text { mandioca, avicultura, cultivo de caju, indústria de confecções, indústria de laticínios, indústria de farinha de } \\
\text { mandioca, indústria de castanha de caju, comércio varejista. }\end{array}$ \\
\hline Médio Oeste & $\begin{array}{l}\text { Cultivo de milho e feijão, cultivo de caju, cultivo de alho, piscicultura, caprinocultura, ovinocultura, apicultura, } \\
\text { indústria de castanha de caju, indústria de laticínios, fruticultura, exploração mineral (calcário, gipsita, } \\
\text { petróleo, água mineral), comércio varejista. }\end{array}$ \\
\hline
\end{tabular}


Segundo dados da Federação das Indústrias do Estado do Rio Grande do Norte (FIERN) sobre o comércio exterior, entre 2007 e 2014 (tabela 2), das atividades econômicas potiguares as que se destacaram, no referido período, nos fluxos de exportações, foram a fruticultura irrigada, desenvolvida no Vale do Açu e na Região de Mossoró, a piscicultura e a carcinicultura, desenvolvidas no litoral oriental e no Vale do Açu; a atividade petrolífera na produção de combustíveis e lubrificantes, localizada na Região de Macau-Guamaré; a indústria de confecções e têxtil, desencadeada no Seridó e no litoral oriental; a atividade salineira, desenvolvida na Região de Macau-Guamaré; a indústria de açúcar e a produção de balas e bombons, localizadas no litoral oriental; e o cultivo de caju, desenvolvido na quase totalidade das regiões do estado.

Tabela 2. Rio Grande do Norte - Comércio exterior entre 2007 e 2014s. Fonte: FIERN, Dados estatísticos sobre comércio exterior, 2015.

\begin{tabular}{|c|c|c|c|c|c|c|}
\hline \multirow[b]{2}{*}{ Ano } & \multicolumn{2}{|c|}{ Balança comercial } & \multirow[b]{2}{*}{$\begin{array}{c}\text { Principais } \\
\text { produtos } \\
\text { exportados } \\
\text { (vendas em US\$) }\end{array}$} & \multirow[b]{2}{*}{$\begin{array}{c}\text { Principais destinos das } \\
\text { exportações (\% de } \\
\text { participação) }\end{array}$} & \multirow{2}{*}{$\begin{array}{c}\text { Principais } \\
\text { produtos } \\
\text { importados } \\
\text { (compras em } \\
\text { US\$) }\end{array}$} & \multirow{2}{*}{$\begin{array}{c}\text { Principais países } \\
\text { de origem das } \\
\text { importações } \\
\text { (\% de } \\
\text { participação) } \\
\end{array}$} \\
\hline & $\begin{array}{l}\text { Exportações } \\
\text { (vendas em } \\
\text { R\$) }\end{array}$ & $\begin{array}{l}\text { Importações } \\
\text { (compras } \\
\text { em R\$) }\end{array}$ & & & & \\
\hline 2007 & 380.128 .187 & 151.638 .228 & $\begin{array}{l}\text { Melão, castanha } \\
\text { de caju, } \\
\text { camarão, banana } \\
\text { e balas e } \\
\text { bombons. }\end{array}$ & $\begin{array}{l}\text { União Europeia (com } \\
\text { destaque para a Holanda e o } \\
\text { Reino Unido), NAFTA (com } \\
\text { destaque para os Estados } \\
\text { Unidos) e África (com } \\
\text { destaque para a Nigéria). }\end{array}$ & $\begin{array}{l}\text { Máquinas e } \\
\text { equipamentos, } \\
\text { polímeros e } \\
\text { plásticos, trigo, } \\
\text { caixas de papelão } \\
\text { e tubos de } \\
\text { ferro/aço. }\end{array}$ & $\begin{array}{l}\text { Estados Unidos, } \\
\text { Argentina } \quad \mathrm{e} \\
\text { Alemanha. }\end{array}$ \\
\hline 2008 & 348.091 .062 & 207.210.261 & $\begin{array}{l}\text { Melão, castanha } \\
\text { de caju, } \\
\text { consumo de } \\
\text { bordo*, açúcar e } \\
\text { camarão. }\end{array}$ & $\begin{array}{l}\text { União Europeia (com } \\
\text { destaque para a Holanda e a } \\
\text { Espanha), NAFTA (com } \\
\text { destaque para os Estados } \\
\text { Unidos) e África (com } \\
\text { destaque para a Tunísia e } \\
\text { Angola). }\end{array}$ & $\begin{array}{l}\text { Trigo, plásticos e } \\
\text { polímeros, tubos } \\
\text { de ferro e aço, } \\
\text { máquinas e } \\
\text { equipamentos } \\
\text { (têxteis, } \\
\text { mecânicos, } \\
\text { elétricos, } \\
\text { médicos) } \\
\text { respectivas peças. }\end{array}$ & $\begin{array}{l}\text { Estados Unidos, } \\
\text { Alemanha } \mathrm{e} \\
\text { Argentina. }\end{array}$ \\
\hline 2009 & 258.103 .664 & 149.867 .637 & $\begin{array}{l}\text { Melão, castanha } \\
\text { de caju, açúcar, } \\
\text { balas e bombons } \\
\text { e camarão. }\end{array}$ & $\begin{array}{l}\text { União Europeia (com } \\
\text { destaque para a Holanda e a } \\
\text { Espanha), NAFTA (com } \\
\text { destaque para os Estados } \\
\text { Unidos) e África (com } \\
\text { destaque para a Nigéria e a } \\
\text { Líbia). }\end{array}$ & $\begin{array}{l}\text { Plásticos e } \\
\text { polímeros, tubos } \\
\text { e obras de ferro e } \\
\text { aço, máquinas e } \\
\text { equipamentos } \\
\text { (têxteis, } \\
\text { mecânicos, } \\
\text { elétricos, } \\
\text { médicos), trigo e } \\
\text { alho. }\end{array}$ & $\begin{array}{l}\text { Estados Unidos, } \\
\text { Argentina } \\
\text { China. }\end{array}$ \\
\hline 2010 & 284.738 .231 & 319.287 .288 & $\begin{array}{l}\text { Castanha de } \\
\text { caju, melão, } \\
\text { açúcar, banana e } \\
\text { sal. }\end{array}$ & $\begin{array}{l}\text { União Europeia (com } \\
\text { destaque para a Holanda e a } \\
\text { Espanha), NAFTA (com } \\
\text { destaque para os Estados } \\
\text { Unidos) e Mercosul (com } \\
\text { destaque para a Argentina). }\end{array}$ & $\begin{array}{l}\text { Eletrogeradores } \\
\text { eólicos e } \\
\text { polipropileno, } \\
\text { plásticos e } \\
\text { polímeros, tubos } \\
\text { e obras de ferro e } \\
\text { aço, máquinas e } \\
\text { equipamentos e } \\
\text { trigo. }\end{array}$ & $\begin{array}{l}\text { Índia, } \quad \text { Estados } \\
\text { Unidos } \\
\text { Argentina. }\end{array}$ \\
\hline
\end{tabular}




\begin{tabular}{|c|c|c|c|c|c|c|}
\hline 2011 & 281.181 .417 & 242.597 .818 & $\begin{array}{l}\text { Melão, castanha } \\
\text { de caju, } \\
\text { consumo de } \\
\text { bordo, peixe e } \\
\text { banana. }\end{array}$ & $\begin{array}{l}\text { União Europeia (com } \\
\text { destaque para a Holanda e a } \\
\text { Espanha), NAFTA (com } \\
\text { destaque para os Estados } \\
\text { Unidos) e Ásia (com } \\
\text { destaque para o Japão e a } \\
\text { China). }\end{array}$ & $\begin{array}{l}\text { Trigo, milho, } \\
\text { polietileno, } \\
\text { máquinas e } \\
\text { equipamentos } \\
\text { diversos e fios } \\
\text { sintéticos. }\end{array}$ & $\begin{array}{l}\text { Argentina, } \\
\text { Estados Unidos e } \\
\text { China. }\end{array}$ \\
\hline 2012 & 261.223 .815 & 222.318 .158 & $\begin{array}{l}\text { Melão, castanha } \\
\text { de caju, } \\
\text { consumo de } \\
\text { bordo, balas e } \\
\text { bombons e } \\
\text { peixe. }\end{array}$ & $\begin{array}{l}\text { União Europeia (com } \\
\text { destaque para a Holanda e a } \\
\text { Espanha), NAFTA (com } \\
\text { destaque para os Estados } \\
\text { Unidos) e Mercosul (com } \\
\text { destaque para a Argentina e } \\
\text { o Uruguai). }\end{array}$ & $\begin{array}{l}\text { Trigo e farinha de } \\
\text { trigo, polietileno, } \\
\text { fios sintéticos e } \\
\text { tecidos de } \\
\text { algodão, coque } \\
\text { de petróleo e } \\
\text { plásticos e } \\
\text { polímeros. }\end{array}$ & $\begin{array}{l}\text { Argentina, China } \\
\text { e Estados Unidos. }\end{array}$ \\
\hline 2013 & 247.922 .375 & 265.995 .557 & $\begin{array}{l}\text { Melão, castanha } \\
\text { de caju, balas e } \\
\text { bombons, } \\
\text { consumo de } \\
\text { bordo e tecidos } \\
\text { de algodão. }\end{array}$ & $\begin{array}{l}\text { União Europeia (com } \\
\text { destaque para a Holanda e a } \\
\text { Espanha), NAFTA (com } \\
\text { destaque para os Estados } \\
\text { Unidos) e Mercosul (com } \\
\text { destaque para a Argentina). }\end{array}$ & $\begin{array}{lr}\text { Trigo, } \\
\text { eletrogeradores e } \\
\text { partes, coque de } \\
\text { petróleo, } \\
\text { plásticos } & \text { e } \\
\text { polímeros } & \text { e } \\
\text { tecidos } & \text { de } \\
\text { algodão } & \text { e } \\
\text { sintéticos. } & \end{array}$ & $\begin{array}{l}\text { Estados Unidos, } \\
\text { China } \\
\text { Argentina. }\end{array}$ \\
\hline 2014 & 251.356 .829 & 313.697 .343 & $\begin{array}{l}\text { Melão, tecidos } \\
\text { de algodão, } \\
\text { castanha de caju, } \\
\text { sal e chapas } \\
\text { plásticas. }\end{array}$ & $\begin{array}{l}\text { União Europeia (com } \\
\text { destaque para a Holanda e a } \\
\text { Espanha), NAFTA (com } \\
\text { destaque para os Estados } \\
\text { Unidos), Aladi (com exceção } \\
\text { do México) e Mercosul (com } \\
\text { destaque para o Peru e a } \\
\text { Colômbia). }\end{array}$ & $\begin{array}{l}\text { Trigo, fornos e } \\
\text { equipamentos } \\
\text { para indústria de } \\
\text { cimento, } \\
\text { geradores eólicos, } \\
\text { cimentos não } \\
\text { pulverizados, } \\
\text { coque de } \\
\text { petróleo. }\end{array}$ & $\begin{array}{lr}\text { China, } & \text { Estados } \\
\text { Unidos } & \mathrm{e} \\
\text { Espanha. } & \end{array}$ \\
\hline
\end{tabular}

* Consumo de bordo refere-se à produção de combustíveis e lubrificantes pela atividade petrolífera.

No período 2007-2014, a balança comercial do Rio Grande do Norte ficou positiva em um número maior de anos, com a realização de mais exportações do que importações, com exceção do ocorrido nos anos de 2010, 2013 e 2014. As exportações de produtos potiguares vêm sendo destinadas principalmente para a União Europeia (com destaque para a Holanda e a Espanha) e para o Tratado Norte-Americano de Livre Comércio (NAFTA) (com destaque para os Estados Unidos). No que se refere às importações, os agentes hegemônicos do mercado potiguar vêm, mormente, comprando trigo, fornos e equipamentos para indústria de cimento, geradores eólicos, cimento não pulverizado, coque de petróleo, plásticos e polímeros, tecidos de algodão e sintéticos, tubos e obras de ferro e aço, máquinas e equipamentos têxteis e médicos e respectivas peças bem como caixas de papelão. Esses produtos vêm sendo importados, comumente, dos Estados Unidos, da Argentina e da China.

Os fluxos destinados ao comércio exterior vêm sendo efetivados pelos eixos rodoviários que macroestruturam o território potiguar: Natal-Mossoró, por meio do qual circulam, principalmente, frutas, castanha de caju, tecidos de algodão, produtos animais impróprios para alimentação humana, lagosta, tungstênio e balas, em direção ao Porto de Pecém (CE) ou ao de Natal; Natal-Fronteira Paraibana, com a circulação de balas, chapas plásticas, tecidos de algodão, granito, tungstênio e açúcar, em direção ao Porto de 
Suape (PE); Natal-Macau - conectado ao eixo Natal-Mossoró - para o transporte de sal, em direção ao Porto Ilha de Areia Branca assim como para a circulação de combustíveis e lubrificantes rumo à capital estadual; e Natal-Caicó, com o transporte de produtos da indústria de confecções em direção à capital norte-riograndense.

Por meio desses eixos rodoviários, os produtos são transportados, geralmente, de sua região de origem para os portos de onde serão exportados. No território estadual, o Porto de Natal é o principal objeto técnico existente para o comércio exterior, escoando, sobretudo, frutas, peixe, tungstênio, camarão e produtos animais impróprios para alimentação humana. Em 2014, esse porto fez fluir 19,4\% do total das exportações do estado, contudo suas limitadas dimensões contribuíram para que sua capacidade de exportação não fosse constantemente amplificada no período 2007-2014, motivo que também ajuda a entender o fato de a maior parte dos fluxos de exportação do Rio Grande do Norte ser realizada pelo porto de Pecém e, em menor medida, pelo de Suape.

Das atuais atividades econômicas desenvolvidas no território potiguar e voltadas, de certo modo, ao mercado externo, apenas a indústria de confecções está localizada no eixo rodoviário Natal-Caicó. Parece-nos que esse é um fato importante para a situação desse eixo no sistema de movimentos do Rio Grande do Norte: seu destaque é para o transporte de passageiros entre municípios do estado, e não para a circulação de cargas. Além disso, pensamos que a escassez de atividades hegemônicas exportadoras no território estudado pode ser um fator explicativo para a predominância de atividades do circuito inferior na dinâmica das cidades que constituem o eixo rodoviário Natal-Caicó, sobretudo de atividades dos ramos comercial ou de prestação de serviços. Assim, pensamos que, diante da falta de empregos ofertados por circuitos econômicos hegemônicos, é por meio do circuito inferior que a maioria dos trabalhadores das cidades desse eixo rodoviário se ocupam e conseguem renda para sobreviver.

Para compreendermos melhor a atual dinâmica do eixo rodoviário Natal-Caicó, é importante atentarmos para as atividades outrora desenvolvidas nesse território, para seu processo de urbanização e para a formação e a atual predominância do circuito inferior da economia urbana. Fazendo isso, evidenciaremos a história que fez do eixo rodoviário Natal-Caicó um território configurado pela rarefação de atividades hegemônicas e pela densidade de atividades do circuito inferior.

\section{A dinâmica econômica da formação territorial e do desenvolvimento urbano inicial do eixo rodoviário Natal-Caicó}

A formação dos espaços que constituem o eixo Natal-Caicó foi, até a década de 1970, alicerçada na pecuária, na produção de algodão, na mineração e na produção de alimentos para o abastecimento da população local: feijão, milho, farinha de mandioca, leite, carne, frango, ovos. Essas atividades possibilitaram 
que ocorresse o povoamento do referido território e, posteriormente, a complexificação de sua estrutura socioeconômica, com a organização de cidades.

A pecuária foi a primeira atividade de fôlego econômico desenvolvida no eixo Natal-Caicó. Entre os séculos XVII e XVIII, ela possibilitou a interiorização do processo de colonização do Rio Grande do Norte (MONTEIRO, 2008) bem como a gênese da articulação territorial entre núcleos urbanos em formação no referido eixo. $\mathrm{O}$ gado era criado no Sertão do estado e transportado a pé para o litoral, onde era abatido e comercializado. No decorrer do caminho do gado foram sendo desenvolvidas atividades produtivas, comerciais e de prestação de serviços para atender demandas dos vaqueiros. Destarte, podemos atribuir ao desenvolvimento da pecuária o nascimento de atividades econômicas desenvolvidas às margens de caminhos de fluxos de pessoas e mercadorias bem como a configuração inicial e lenta das cidades que hoje caracterizam o eixo estudado.

No século XVIII, no contexto da Revolução Industrial e da demanda internacional da indústria têxtil por matéria-prima, outra atividade de destaque econômico começou a ser desenvolvida no eixo Natal-Caicó, sobretudo, nas cidades seridoenses: a algodoeira. $O$ algodão foi cultivado nas terras mais férteis existentes, geralmente consorciado às culturas alimentares. Seu cultivo foi acompanhado, já nos séculos XIX e XX, pela instalação de usinas para seu beneficiamento e de fábricas para industrialização de derivados, fato que contribuiu para a complexificação da organização espacial dos núcleos urbanos em formação. Além disso, passou a ocorrer, nesses núcleos,

[...] a instalação de instituições públicas e privadas para fins de prestação de serviços à comunidade; [a] construção e [o] asfaltamento de estradas como forma de interligar as áreas produtoras e facilitar o escoamento da produção; [a] instalação do sistema de telefonia fundamental à articulação com o mercado consumidor e [a] implantação de órgãos de pesquisa dedicados a estudos e experimentos relativos ao algodão, principalmente (MORAIS, 2005a, p. 04).

Desse modo, asseveramos que a atividade algodoeira foi importante, no século XIX, para adensar a organização das cidades e a vida urbana no eixo Natal-Caicó, bem como, no século XX, especificamente entre as décadas de 1940 e 1970, para intensificar o processo de urbanização do território, tornando mais célere o crescimento das cidades e realçando o papel destas como centros comerciais e de prestação de serviços.

Destacamos, entretanto, que, segundo Souza (2000), a atividade algodoeira, desenvolvida no Nordeste brasileiro entre a primeira e a segunda metades do século XX, não era capaz de gerar empregos para todos os trabalhadores que migravam do campo para a cidade atraídos pela melhor infraestrutura desse espaço e pelas maiores possibilidades que ele já apresentava. Desse modo, o autor sublinha que o relatório do Grupo de Trabalho para o Desenvolvimento do Nordeste (GTDN) afirmava que, nos anos de 1950, expressivo contingente de trabalhadores não conseguia emprego na cotonicultura e buscava sua sobrevivência em atividades comerciais ou de prestação de serviços, que os ocupava, mas não os empregava. Portanto, a fal ta 
de empregos para todos os trabalhadores urbanos apresentou-se como razão importante para que atividades não hegemônicas fossem realizadas, para atender demandas existentes no meio urbano bem como para garantir a sobrevivência dos trabalhadores não empregados.

A intensificação da urbanização do Rio Grande do Norte e, particularmente, do eixo Natal-Caicó, no século XX, não ocorreu motivada apenas pela continuidade do desenvolvimento da pecuária e pela efervescência da atividade algodoeira. Outra atividade econômica voltada ao mercado internacional contribuiu sobremaneira para tal intensificação: a mineração.

Também desenvolvida nas cidades seridoenses, principalmente em Currais Novos, a exploração da scheelita, mineral vendido para os Estados Unidos, para ser usado na indústria bélica, durante a Segunda Guerra Mundial (1939-1945), gerou divisas que foram utilizadas para melhor estruturar as cidades mineradoras. Morais (2005b) sublinha que, em Currais Novos, por exemplo, foi instalada Agência do Banco do Brasil e rádio local assim como construídos hotel, pista de pouso, cineteatro e uma vila para moradia dos operários da mineração. Sendo assim, a atividade mineradora foi importante para gerar empregos e para ampliar a função comercial e de prestação de serviços das cidades.

Portanto, entre as décadas de 1940 e 1970, as atividades hegemônicas desencadeadas no eixo NatalCaicó contribuíram para a implantação de infraestruturas e para a geração de empregos e ocupações nas cidades, fato que as tornou atrativas e conferiu veemência ao processo de urbanização do território. Até então, a urbanização ocorria atrelada ao desencadeamento de circuitos econômicos interessantes ao mercado externo e predominantes no âmbito estadual.

Nas décadas de 1970 e 1980, aspectos das conjunturas internacional e nacional e da estrutura produtiva estadual ocasionaram a crise das economias hegemônicas tradicionais quanto ao processo de formação territorial e desenvolvimento urbano inicial do eixo rodoviário Natal-Caicó. Entrou então em colapso a cotonicultura potiguar, devido, sobretudo, à baixa produtividade alcançada pelos produtores estaduais, à diminuição do preço do algodão no mercado mundial, à modernização e desconcentração geográfica da indústria têxtil paulista e ao surgimento e à proliferação da praga do bicudo nos algodoeiros do Rio Grande do Norte (MORAIS, 2005b). A crise da cotonicultura ocasionou também dificuldades na pecuária, tendo-se em vista que os cultivadores e beneficiadores de algodão eram também, geralmente, criadores de gado, e as perdas monetárias sofridas diante do colapso da atividade algodoeira acabaram afetando, conjuntamente, a pecuária.

Na década de 1980, também entrou em crise a mineração desencadeada no território potiguar, em decorrência, conforme Morais (2005b), da queda do preço da scheelita no mercado mundial, ocasionada pelo significativo ingresso da China no contexto da exploração e da comercialização do minério em escala global, e 
pela falta de competitividade da produção desenvolvida no Rio Grande do Norte com a que já era realizada na China, a qual se caracterizava por maior nível tecnológico e pelos menores preços do minério.

A dinâmica econômica da intensificação do processo de urbanização e modernização econômica do Rio Grande do Norte e do eixo rodoviário Natal-Caicó

As crises acima mencionadas fizeram ruírem os pilares da tradicional dinâmica socioeconômica que marcou a formação do eixo Natal-Caicó. A perda de dinamismo da pecuária, da cotonicultura e da mineração ocasionou o desemprego de muitos trabalhadores e a aceleração da migração de pessoas do campo para a cidade. A partir de então, a configuração territorial do referido eixo rodoviário foi alterada, com a frequente diminuição ou a estabilização da população rural e o aumento significativo da população urbana (tabela 3) bem como a expansão das atividades comerciais e de prestação de serviços desenvolvidas nas cidades, por meio das quais a maioria dos trabalhadores passou a buscar sua sobrevivência.

Tabela 3. Eixo rodoviário Natal-Caicó e Rio Grande do Norte - População urbana e rural residente entre 1970 e 2010. Fonte: IBGE/SIDRA, 2014.

\begin{tabular}{|c|c|c|c|c|c|c|c|c|c|c|}
\hline \multirow{2}{*}{ Municípios } & \multicolumn{5}{|c|}{ População urbana } & \multicolumn{5}{|c|}{ População rural } \\
\hline & 1970 & 1980 & 1991 & 2000 & 2010 & 1970 & 1980 & 1991 & 2000 & 2010 \\
\hline Natal & 257.466 & 416.892 & 606.887 & 712.317 & 803.739 & 6.913 & - & - & - & - \\
\hline Parnamirim & 9.922 & 19.835 & 48.593 & 109.139 & 202.456 & 4.580 & 6.527 & 14.719 & 15.551 & - \\
\hline Macaíba & 9.929 & 17.029 & 29.019 & 36.041 & 42.631 & 19.197 & 14.241 & 14.431 & 18.842 & 26.836 \\
\hline Bom Jesus & 1.697 & 2.137 & 4.430 & 6.223 & 6.768 & 1.573 & 2.457 & 2.767 & 2.385 & 2.672 \\
\hline Senador Elói de Souza & 651 & 753 & 1.256 & 2.093 & 2.423 & 3.036 & 3.329 & 3.053 & 2.935 & 3.214 \\
\hline Serra Caiada & 1.600 & 2.030 & 3.023 & 3.959 & 5.313 & 2.885 & 2.990 & 2.972 & 3.046 & 3.455 \\
\hline Tangará & 3.175 & 4.237 & 6.258 & 8.109 & 9.734 & 4.252 & 4.424 & 3.955 & 4.009 & 4.441 \\
\hline Santa Cruz & 9.906 & 13.180 & 21.783 & 24.507 & 30.499 & 10.417 & 9.152 & 6.871 & 6.787 & 5.298 \\
\hline Campo Redondo & 2.090 & 3.047 & 4.205 & 4.822 & 5.197 & 7.153 & 6.133 & 5.144 & 4.379 & 5.069 \\
\hline Currais Novos & 15.863 & 25.674 & 33.819 & 35.529 & 37.777 & 10.316 & 9.305 & 6.408 & 5.262 & 4.875 \\
\hline Acari & 5.267 & 6.520 & 7.807 & 8.841 & 8.902 & 5.631 & 4.498 & 3.176 & 2.348 & 2.133 \\
\hline Jardim do Seridó & 4.215 & 6.422 & 8.550 & 9.297 & 9.835 & 4.691 & 3.932 & 3.290 & 2.744 & 2.278 \\
\hline Caicó & 24.427 & 30.828 & 42.783 & 50.624 & 57.461 & 12.094 & 9.202 & 7.857 & 6.378 & 5.248 \\
\hline $\begin{array}{l}\text { Eixo rodoviário Natal- } \\
\text { Caicó - Total }\end{array}$ & 346.208 & 548.584 & 818.413 & 1.011 .501 & 1.222 .735 & 92.738 & 76.190 & 74.643 & 74.666 & 65.519 \\
\hline Rio Grande do Norte & 736.615 & 1.115 .279 & 1.669 .267 & 2.033 .775 & 2.465 .042 & 813.569 & 783.556 & 746.300 & 743.733 & 702.985 \\
\hline
\end{tabular}

A migração do campo para a cidade é um aspecto imprescindível para se compreender a intensificação da urbanização do Rio Grande do Norte, especificamente do eixo Natal-Caicó a partir de 1970. A falta de dinamismo das economias agrícolas tradicionais do território e a ausência de novas atividades no campo tornaram escassos os empregos e as ocupações nesse espaço. Soma-se a isso a desigual estrutura fundiária do campo estadual (INCRA/Atlas fundiário brasileiro, 2014) e as secas periódicas que há tempos caracterizam o território estudado, fazendo com que muitos trabalhadores, sobretudo os pobres, sem emprego, sem 
ocupação e sem terra para cultivar, se deslocassem para a cidade, em busca de melhores rendimentos e condições de vida.

Entretanto, o crescimento da população urbana, com a crise da pecuária e da cotonicultura, não foi acompanhado, na mesma medida, pela expansão da infraestrutura urbana e pela geração de empregos na cidade, devido, também, à crise da mineração. Assim, tal crescimento populacional significou amplificação da pobreza urbana, sendo impulsionado pelo desencadeamento de atividades do circuito inferior da economia, principalmente de atividades comerciais e de prestação de serviços.

A expansão das atividades do circuito inferior da economia impulsionou a intensificação da urbanização do eixo Natal-Caicó, tendo-se em vista a pouca dinamicidade das atividades agrícolas aí existentes, assim como a incipiente atividade industrial do território, que não atende a maioria das demandas por emprego. A produção industrial hegemônica não selecionou o eixo Natal-Caicó como espaço de densidade, conferindoIhe apenas algumas unidades produtivas, sobretudo do ramo têxtil. Assim, tal processo de urbanização organizou o território com a predominância das atividades não hegemônicas, mas o fator estrutural sendo as relações existentes entre os circuitos da economia urbana.

Essas relações só se tornaram possíveis com a intensificação do processo de urbanização do território, em decorrência das mudanças socioeconômicas ocasionadas pelas forças da modernização. Isso porque, antes dessa intensificação, não havia, no eixo rodoviário Natal-Caicó, um crescimento urbano demasiado, nem mesmo atividades econômicas não hegemônicas integradas com indústrias ou empresas hegemônicas. Sendo assim, até a década de 1970, a organização das cidades do eixo era calcada no tripé gado-algodão-mineração e no desenvolvimento de atividades comerciais e prestadoras de serviços limitadas ao âmbito local, por atenderem, prioritariamente, demandas de moradores locais e se abastecerem no próprio município de localização.

A intensificação da urbanização e da modernização do território fez com que a organização das cidades do eixo passasse a ser caracterizada pela coexistência de atividades não hegemônicas com atividades do circuito superior da economia, estas ofertando comercialização e serviços modernos, o que vem modificando a tradicional organização criativa daquelas atividades. Além disso, empresas do circuito superior não localizadas no eixo Natal-Caicó passaram a encaminhar representantes comerciais a suas cidades, atendendo demandas por mercadorias de atividades do circuito inferior. $\mathrm{O}$ abastecimento desse circuito por aquele contribui ainda mais para emaranhar a organização das atividades não hegemônicas, as quais, hoje, dificilmente são desenvolvidas com ausência de capital e de técnicas modernas bem como vêm ampliando sua escala de atuação, não se limitando mais ao contexto local, sobretudo no que se refere à compra de mercadorias transformadas e/ou comercializadas. 
Por isso, asseveramos que os circuitos da economia urbana começaram a coexistir no eixo rodoviário Natal-Caicó com a intensificação do processo de urbanização e modernização do território, tendo-se em vista que é só a partir de então que as relações entre circuito superior e circuito inferior nesse eixo se tornam possíveis. Antes da década de 1970, as atividades econômicas urbanas existentes no eixo não constituíam o circuito inferior ou o circuito superior porque tais circuitos só existem em relação, o que naquela época não era possível, em decorrência da dinâmica econômica predominantemente agrícola e de o crescimento urbano elevado ainda não ser uma realidade.

Assim, no período atual, a urbanização do eixo Natal-Caicó é estruturada nas relações de complementaridade, concorrência e subordinação entre os circuitos da economia urbana. Assim, a predominância quantitativa - número de atividades existentes - e qualitativa - contribuição para o uso do território pela maioria dos trabalhadores - é do circuito inferior ${ }^{4}$, mas o comando da dinâmica econômica e, de certo modo, da organização territorial é do circuito superior, que, cada vez mais, determina a incorporação de variáveis-chave do período atual pela economia não hegemônica.

Dados do MTE/RAIS (2014) esmiúçam a dinâmica econômica da intensificação do processo de urbanização e modernização econômica do Rio Grande do Norte e dos municípios que constituem o eixo rodoviário Natal-Caicó no período de 1985 até 2012. Tais dados dizem respeito apenas às atividades econômicas registradas junto ao poder público e aos vínculos empregatícios, não abrangendo as atividades não registradas e as ocupações sem vínculo empregatício. Contudo, apesar de não abarcarem a totalidade das atividades existentes, são dados importantes, pois mostram, com certa eficácia, aspectos da realidade vivenciada e se tornam mais importantes e eficazes diante do esforço que fazemos de relacioná-los com reflexões que desenvolvemos visando compreender a dinâmica urbana do citado eixo.

Assim sendo, sublinhamos que, hoje, na economia do eixo rodoviário Natal-Caicó, coexistem atividades agrícolas e urbanas tradicionais com atividades urbanas recentes, havendo, desse modo, a integração das economias agrícola e urbana e o estabelecimento de circuitos espaciais produtivos, como o da indústria têxtil. A economia urbana é, predominantemente, marcada por pequenos negócios dos ramos comercial e de prestação de serviços, merecendo também realce as atividades de serviços ligadas à administração pública ou técnica. Outrossim, as pequenas atividades produtivas devem ter sua importância destacada, principalmente as dos ramos têxtil e de alimentos.

\footnotetext{
4 Dados quantitativos e qualitativos decorrentes da pesquisa de campo que realizamos explicitam a proeminência do circuito inferior da economia urbana no eixo rodoviário Natal-Caicó. Quantitativamente, esse subsistema equivale a 70\% das atividades existentes no eixo. Qualitativamente, tem importância na dinâmica do território, ao usar e banalizar variáveis do período atual, possibilitar ocupação e renda para a maioria dos trabalhadores e explicitar o território usado como fator de desigualdades, alternativas e resistências.
} 
No que tange ao tamanho dos estabelecimentos econômicos, no Rio Grande do Norte e, particularmente, no eixo rodoviário Natal-Caicó, entre 1985 e 2012, foi constante e veemente o crescimento do número de micro e pequenas atividades assim como daquelas que eram desenvolvidas apenas por seu responsável. No total, a grande maioria das atividades existentes era de micronegócios, empregando, sobretudo, de 1 a 4 pessoas e, em menor amplitude, de 5 a 9 pessoas (MTE/RAIS, 2014).

Os micros e pequenos estabelecimentos também vêm se destacando quanto ao número de vínculos empregatícios gerados. Entre 1985 e 2012, tanto no Rio Grande do Norte quanto no eixo rodoviário NatalCaicó, com exceção dos estabelecimentos com 50 a 99 empregados, houve crescimento constante no número de vínculos ativos em todos os outros estabelecimentos. No total, desde 2000, a maioria dos vínculos empregatícios vem sendo gerada nos micros e pequenos estabelecimentos, sendo que, nas cidades locais, tais vínculos são, quase totalmente, gerados nesses estabelecimentos.

Além do tamanho reduzido, as atividades econômicas urbanas do eixo rodoviário Natal-Caicó também se caracterizam por serem, predominantemente, comerciais e/ou prestadoras de serviços. Aliás, a intensificação da urbanização do território vem ocorrendo muito mais pela amplificação do número dessas atividades do que pela expansão das atividades industriais ou agropecuárias. Do mesmo modo, asseveramos o crescimento constante, nesse processo, do número de atividades econômicas registradas junto ao poder público, fato que contribui para colocar em xeque a sinonímia errônea que se estabelece entre circuito inferior da economia urbana e informalidade, no que se refere a falta de registro público das atividades desenvolvidas e a falta de vínculos empregatícios nessas atividades. Observamos, na realidade, que há atividades do circuito inferior que são registradas publicamente e que empregam trabalhadores, assim como existem atividades do circuito superior que não possuem registro e apenas ocupam trabalhadores.

Dados do MTE/RAIS (2014) mostram que, já outrora, em 1985 e 1990, tanto no Rio Grande do Norte quanto no eixo rodoviário Natal-Caicó, o comércio concentrava a maioria das atividades com registro junto ao poder público, seguido pelos serviços e, em menor medida, pela indústria, construção civil e agropecuária. O registro público de atividades econômicas ocorria, predominantemente, na capital estadual e, em menor grau, em Caicó, Currais Novos, Parnamirim. Nos centros locais, tal ação era limitada a poucos estabelecimentos que desenvolviam, sobretudo, comércio ou serviços; no que tange aos estabelecimentos industriais, da construção civil ou da agropecuária, nesses centros urbanos quase inexistia o registro junto ao Estado.

Em 2000, no Rio Grande do Norte e no eixo rodoviário Natal-Caicó, o comércio continuava a concentrar a maioria das atividades com registro junto ao poder público, seguido pelos serviços, de certo modo pela indústria e, em menor medida, pela construção civil e a agropecuária. O registro público de atividades econômicas ocorria, predominantemente, na capital estadual e, em menor grau, em Parnamirim, Caicó, Currais Novos, Macaíba. Nos centros locais, em relação aos anos anteriores, houve certa expansão do registro 
dos estabelecimentos que desenvolviam comércio, serviços e, minoritariamente, produção; no que tange aos estabelecimentos da construção civil ou da agropecuária, quase inexistia o registro junto ao Estado (MTE/RAIS, 2014).

Em 2012, os resultados foram bastante parecidos com os de 2000; o que difere é a elevação considerável do número de estabelecimentos da construção civil com registro junto ao poder público, tanto no Rio Grande do Norte quanto, particularmente, no eixo rodoviário Natal-Caicó (MTE/RAIS, 2014).

De 1985 até 2012, as atividades comerciais que predominavam na economia urbana do Rio Grande do Norte e do eixo rodoviário Natal-Caicó eram as do comércio varejista, seguidas pelas atividades prestadoras de serviços. A propósito destas, em 1985 e 1990, o destaque foi dos serviços de alojamento, alimentação, reparação, manutenção. Em 2000, ficou com os serviços de alojamento, de comunicação e de administração técnica profissional. E, em 2012, os serviços de administração técnica profissional superaram os de alojamento e os de comunicação (MTE/RAIS, 2014).

O realce das atividades comerciais e de prestação de serviços, no eixo rodoviário Natal-Caicó, não é só quantitativo, mas também qualitativo. Conforme já explanamos, com a intensificação do processo de urbanização e modernização econômica do território, as relações entre os circuitos da economia urbana se tornaram mais veementes, apresentando-se como estruturais para o desencadeamento desse processo. Tais relações possibilitam a amplificação da divisão do trabalho, com o nascimento de novas atividades de comércio e de serviços, ofertando-se mercadorias e ações anteriormente não existentes e, assim, diversificando-se o mercado. Além disso, o nascimento de novas atividades conjugado à incorporação de variáveis-chave do período atual em atividades do circuito inferior da economia urbana são fatores que trazem à tona a especialização técnica e profissional de serviços outrora desenvolvidos sem a utilização de técnicas modernas, apenas com base na curiosidade ou na aprendizagem não curricular de agentes do circuito inferior. Essa realidade marca a dinâmica de todas as cidades do eixo rodoviário, ocorrendo de maneira mais veemente na capital estadual, nas cidades da Região Metropolitana de Natal e nos centros regionais sertanejos, onde as relações entre os circuitos da economia são mais densas.

Do mesmo modo, as atividades comerciais e de serviços são as que mais vêm empregando trabalhadores no Rio Grande do Norte e no eixo rodoviário Natal-Caicó. Entre 1985 e 2012, no eixo rodoviário, houve crescimento constante do número de vínculos empregatícios nos estabelecimentos do comércio e dos serviços. Além disso, esses estabelecimentos eram os que mais empregavam no eixo, seguidos pelas atividades produtivas, da construção civil e da agropecuária, respectivamente. Destacamos também que, entre 2000 e 
2012, houve aumento intensivo do número de empregos em todos os ramos econômicos, com exceção da agropecuária $^{5}$ (MTE/RAIS, 2014).

No Rio Grande do Norte, entre 1985 e 2012, houve crescimento do número de vínculos empregatícios em todos os ramos econômicos, com exceção da agropecuária. Até 2000 , as atividades que mais empregavam no estado eram as prestadoras de serviços, seguidas pelas atividades produtivas. Em 2012, as atividades comerciais superaram as produtivas, ficando atrás apenas dos estabelecimentos de prestação de serviços no número total de empregos. Assim como no eixo Natal-Caicó, entre 2000 e 2012 houve substancial aumento no número de empregos nas atividades dos serviços, do comércio, da indústria e da construção civil (MTE/RAIS, 2014).

De 1985 até 2012, a atividade de serviços que mais empregou trabalhadores no Rio Grande do Norte e no eixo rodoviário Natal-Caicó foi a administração pública, seguida pelos serviços de alojamento, alimentação, reparação, manutenção e pela administração técnica profissional. Já no que se refere ao comércio, foi o varejo que mais empregou (MTE/RAIS, 2014). Tais dados evidenciam a importância do poder público, do turismo, das atividades para alimentação, dos serviços de reparo de objetos pessoais, da profissionalização da administração empresarial e do comércio varejista na geração de postos de emprego no mercado de trabalho potiguar.

Apesar de a densidade da dinâmica econômica do eixo rodoviário Natal-Caicó estar nas pequenas atividades comerciais e de prestação de serviços, não devemos acreditar que a totalidade dessa dinâmica se limite a tais atividades. As atividades agrícolas e produtivas também marcam o território e devem ter sua importância destacada, mesmo que não tenham mais a força econômica que outrora alicerçou a formação do território e o início de sua urbanização.

Desse modo, a agricultura do eixo Natal-Caicó é, hoje, caracterizada pelo cultivo de gêneros alimentícios - feijão, milho - visando, sobretudo, à subsistência das famílias cultivadoras e ao abastecimento do mercado local com o excedente produzido, assim como pela cultura de frutas - goiaba, manga, pinha, graviola, jaca e caju - com caráter eminentemente comercial, isto é, com a possibilidade da venda da totalidade do que é produzido, sem que o consumo da família produtora seja priorizado.

Outro gênero alimentício bastante cultivado no eixo Natal-Caicó é a mandioca. Seu cultivo, de acordo com Salvador (2013), não é prioritariamente voltado para a subsistência das famílias que a produzem, mas,

\footnotetext{
${ }^{5}$ Esse aumento vertiginoso do número de empregos se conecta ao contexto favorável da economia nacional na primeira década do século XX, sobretudo a partir de 2004, quando se alcançou no Brasil crescimento econômico com geração de empregos. Contudo, a análise de dados estatísticos sobre o mercado de trabalho no Rio Grande do Norte, especificamente no eixo Natal-Caicó, evidencia que a expansão dos empregos na primeira década do século XX não serviu para romper com o processo de precarização do trabalho, tendo em vista que a maioria dos empregos gerados foi de baixa qualidade, quanto às condições de trabalho, aos rendimentos obtidos e ao acesso a direitos trabalhistas.
} 
sim, principalmente, ao abastecimento de casas e indústrias de farinha que existem no território. Nas indústrias, produzem-se diversos tipos de farinha de mandioca e de farofa, de acordo com padrões tecnológicos e de higiene orientados pelo Serviço Brasileiro de Apoio às Micro e Pequenas Empresas (SEBRAE) e pelo Instituto de Assistência Técnica e Extensão Rural (EMATER), produção que abastece o mercado nordestino de farinha.

No que tange à pecuária, o gado é criado para a produção de carne, que abastece, principalmente, o mercado local, bem como para a produção de leite, que vem sendo marcada pela incorporação de novas técnicas para beneficiamento, tendo como importante alicerce o Programa do Leite, política pública do governo estadual, que compra leite a pecuaristas do Rio Grande do Norte e o distribui para famílias carentes.

Não obstante as inovações técnicas e organizacionais estarem presentes nas atividades agrícolas desenvolvidas no eixo Natal-Caicó, tais atividades não conseguem ter mais o intenso dinamismo que já tiveram na organização do território, porque não são mais atraentes ao mercado internacional e não oferecem condições significativas de trabalho e bons rendimentos, o que faz com que muitos trabalhadores, antes residentes no campo, prefiram migrar para a cidade em busca de melhores rendimentos e condições de vida.

No que toca às atividades produtivas, dados do MTE/RAIS (2014) mostram que, entre 1985 e 2012, as atividades que se destacaram na geração de empregos foram: a têxtil, a extrativa mineral, a de produção de alimentos e bebidas e a química. Em 1985, no eixo rodoviário Natal-Caicó, as atividades produtivas que mais vinculavam empregados eram a indústria têxtil de vestuário e artefatos de tecido; a de produtos alimentícios, bebidas e álcool etílico; e a extrativa mineral (com destaque para a mineração em Currais Novos). Em 1990, apesar da diminuição do número de empregos em relação a 1985, a indústria têxtil permanecia sendo a que mais empregava, seguida pela de alimentos e bebidas e pela de produtos farmacêuticos, veterinários, perfumaria (com destaque para Parnamirim). Nesse ano, houve forte queda do número de empregos gerados pela indústria extrativa mineral, sobretudo devido ao fraco desempenho da mineração em Currais Novos.

No Rio Grande do Norte, em 1985, a indústria têxtil era a que mais empregava, seguida pela de alimentos e bebidas e pela extrativa mineral. Em 1990, a indústria de alimentos e bebidas assumiu a dianteira no número de vínculos empregatícios, seguida pela têxtil, que reduziu o número de empregos em relação a 1985, e pela de produtos farmacêuticos, veterinários, de perfumaria (MTE/RAIS, 2014).

Em 2000, no eixo rodoviário Natal-Caicó, a indústria têxtil prosseguia sendo a responsável pelo maior número de vínculos empregatícios dentre as atividades produtivas, sendo seguida pela indústria química (com destaque para os ramos dos produtos farmacêuticos, veterinários e de perfumaria), pela produção de minerais não metálicos e pela extrativa mineral (estas duas últimas atividades calcadas, desde então, sobretudo na produção de cerâmicas vermelhas a partir da extração da argila). No Rio Grande do Norte, o destaque foi, 
respectivamente, da indústria têxtil, da extrativa mineral, da de minerais não metálicos e da química (MTE/RAIS, 2014).

Em 2012, no Rio Grande do Norte e no eixo rodoviário Natal-Caicó, a indústria têxtil manteve-se como a responsável pela maior vinculação empregatícia, seguida pela extrativa mineral, pela de minerais não metálicos e pela indústria química (MTE/RAIS, 2014).

O circuito espacial da indústria têxtil se faz presente na quase totalidade do território potiguar, com exceção apenas das regiões do Litoral Norte, do Vale do Açu e do Médio Oeste (SEPLAN/Perfil do Rio Grande do Norte, 2014). Além disso, essa atividade produtiva participa do comércio exterior, destacando-se nos fluxos internacionais de mercadorias, tanto pela exportação de tecidos de algodão e de poliéster e de roupas de cama quanto pela importação de matérias-primas (tecidos de algodão e sintéticos e fios desse material) e de bens de capital (máquinas e equipamentos têxteis) (FIERN/Dados estatísticos sobre comércio exterior, 2015).

Apesar de caracterizar várias regiões do Rio Grande do Norte, o maior destaque da indústria têxtil, na quantidade de estabelecimentos produtivos, de mercadorias produzidas e de pessoal empregado ou ocupado, está em cidades da Região Metropolitana de Natal e do Seridó, muitas das quais integrantes do eixo rodoviário Natal-Caicó, como Parnamirim e Macaíba (cidades da Região de Natal) e Caicó e Jardim do Seridó (cidades seridoenses).

Nas cidades da Região Metropolitana de Natal, a particularidade do circuito produtivo está na densa localização de grandes grupos fabris do referido ramo econômico, como Guararapes, Coteminas, Hering, Vicunha, Coats. Já nas cidades seridoenses, destaca-se a presença de inúmeras bonelarias, que atendem a demandas dos mercados estadual e nacional, inclusive de marcas famosas que as contratam para a fabricação de boné sem a marca. As cidades seridoenses também são particularizadas pela presença de pequenas unidades fabris, muitas das quais residenciais, que produzem redes de dormir, panos de prato e roupas de cama, assim como por unidades de montagem de vestimentas. Estas são pequenas unidades produtivas terceirizadas por grandes empresas, como a Guararapes e a Hering, onde são montadas vestimentas de acordo com as determinações dessas empresas.

A dinâmica econômica atual de cidades locais seridoenses é veementemente marcada pela existência dessas pequenas unidades produtivas de vestimentas. Nelas, muitos trabalhadores, residentes nas cidades onde elas estão localizadas ou em cidades próximas, são empregados ou ocupados, conseguindo, desse modo, sobreviver sem a necessidade de desenvolver uma atividade por conta própria. Contudo, vale também frisar que tais unidades produtivas representam um elemento estratégico central de grandes empresas ou indústrias têxteis, cujo objetivo macro é reduzir os custos com a produção e aumentar a produtividade dos trabalhadores. As grandes empresas ou indústrias têxteis, antes de procurarem uma cidade local para 
terceirizar sua produção, fazem contato com as autoridades políticas locais para que lhes possibilitem as melhores condições disponíveis de uso vantajoso do território selecionado. Assim, por meio das pequenas unidades produtivas têxteis, são subcontratados trabalhadores, com baixos níveis de remuneração e sem acesso a direitos trabalhistas. Fazendo isso, tais empresas ou indústrias garantem seus lucros, resguardam sua marca e contribuem para a precarização do trabalho em escala nacional (ANTUNES, 2006), tendo em vista que essa situação das unidades produtivas têxteis não se limita ao contexto potiguar.

Outra atividade produtiva de destaque na quantidade de empregos gerados no eixo rodoviário NatalCaicó é a indústria ceramista. Nesta, são produzidos tijolos e telhas que abastecem o mercado estadual e o de outros estados nordestinos, empregando ou ocupando muitos trabalhadores das cidades do eixo. Entretanto, essa atividade também ocasiona problemas sociais e ambientais. As condições de trabalho nela são extremamente precárias, sendo os trabalhadores expostos sem segurança à realização de tarefas perigosas, recebendo baixas remunerações e, muitas vezes, contratados sem registro em carteira de trabalho, não tendo, assim, os direitos trabalhistas garantidos. Além disso, a produção de telhas e tijolos é feita de modo bastante degradante para o ambiente, causando intenso desmatamento e poluição do ar. Por isso, asseveramos que a indústria ceramista, assim como a têxtil, contribui para a precarização do trabalho e incrementa sua perversidade para com o território usado pela degradação ambiental que gera ou intensifica.

Além da indústria têxtil e da ceramista, o território do eixo rodoviário Natal-Caicó também é permeado pelas atividades que produzem alimentos e bebidas e artesanato. A indústria de alimentos e bebidas figurou nos dados do MTE/RAIS (2014) referentes a 1985 e a 1990, destacando-se na vinculação de empregados. Contudo, nos anos de 2000 e 2012, ela não teve mais destaque nessa vinculação. Isso poderia nos levar a pensar no enfraquecimento dessa indústria no eixo rodoviário em questão, nos últimos anos.

Ao contrário, a realidade das cidades do eixo evidencia que, na atualidade, as atividades que produzem alimentos e bebidas continuam a existir ou a se expandir no eixo Natal-Caicó, mas caracterizam a situação urbana atual desse território, por meio de micro e pequenas unidades produtivas, muitas das quais caseiras, que produzem biscoitos, pães, bolos, doces, licores etc., os quais são vendidos pelos próprios produtores ou são distribuídos para o comércio local ou regional, que se encarrega de comercializá-los. O que vem ocorrendo com essa indústria é a diminuição do registro público de suas atividades, bem como o enfraquecimento da vinculação de empregados, tendo-se em vista o caráter bastante familiar e domiciliar de suas unidades fabris. Desse modo, hoje, a produção de alimentos e bebidas no eixo rodoviário Natal-Caicó continua em franca expansão, mais ocupando do que empregando trabalhadores.

Do mesmo modo, o artesanato é bastante praticado nas cidades do eixo rodoviário Natal-Caicó, sem que suas atividades sejam, na maioria, registradas junto ao Estado e sem que empregados sejam contratados. Nesse sentido, artesãos produzem, geralmente, em suas casas, bordados e objetos decorativos que são 
vendidos no mercado local ou, no caso das cidades seridoenses, pela fama adquirida dos artesanatos confeccionados, são encontrados em lojas de todo o país (ARAÚJO, 2000). Por meio dessa atividade, também muitas pessoas obtêm ocupação, renda e possibilidade de consumir.

Em suma, a análise feita sobre a dinâmica econômica do eixo rodoviário Natal-Caicó nos leva a asseverar que a maioria das atividades econômicas aí localizadas são de micro ou de pequena dimensões, que sua organização se alicerça, principalmente, na criatividade dos homens pobres, e com relações de trabalho calcadas, sobretudo, nos acordos pessoais, e não em contratos registrados em carteira de trabalho, havendo muito mais ocupações do que empregos. Essas características indicam que a intensificação do processo de urbanização e modernização econômica do eixo rodoviário Natal-Caicó vem ocorrendo via expansão das atividades do circuito inferior da economia urbana e, desse modo, paralelamente ao processo de precarização das relações e do mercado de trabalho. Trata-se de uma urbanização estruturada nas relações entre a economia hegemônica e a economia não hegemônica coexistentes no território, com a complementação subordinada do circuito inferior ao circuito superior.

\section{CONCLUSÃO: a intensificação da urbanização do eixo rodoviário Natal-Caicó pela expansão do circuito} inferior da economia urbana

A expansão do circuito inferior da economia urbana decorre de vários fatores, como a ordem econômica estrutural ou conjuntural ou a própria natureza desse subsistema na atualidade. No eixo rodoviário NatalCaicó, tal expansão ocorre com a crise econômica que perpassa o território desde a derrocada das economias tradicionais que alicerçaram sua formação e dinamizaram o mercado de trabalho de outrora com a geração de empregos. A partir da década de 1970, os empregos diminuíram sensivelmente na área rural dos municípios do eixo, fazendo com que houvesse uma elevada migração em direção às cidades. Nestas, ao invés da implementação de novas atividades econômicas que gerassem empregos, o que ocorreu foi o desenvolvimento de micro e pequenas atividades comerciais e de prestação de serviços calcadas, sobretudo, no trabalho por conta própria ou familiar. Sendo assim, a maioria dos trabalhadores pobres não conseguiu emprego na cidade e, visando sua sobrevivência, procurou ocupações que lhes possibilitassem geração de renda e acesso a bens de consumo necessários à vida.

Dessa maneira, vem à baila outro aspecto que contribui para a expansão do circuito inferior: a capacidade dos trabalhadores pobres de inventar alternativas para sua sobrevivência. Encontrando-se em uma situação de desemprego, sem grandes perspectivas de alteração dessa situação, devido à rarefação de atividades econômicas que atendam às demandas por emprego, e sem acesso a direitos sociais estatais que possam, ao menos, minimizar a gravidade de tal situação, os trabalhadores pobres do eixo Natal-Caicó vêm lutando pelo uso do território, desenvolvendo atividades econômicas, na sua maioria comerciais ou de 
serviços, que Ihes possibilitem a sobrevivência. As ações desses trabalhadores, ao contrário das ações estatais de proteção social, vêm sendo de tamanha amplitude que, hoje, predomina na economia urbana do eixo rodoviário em questão o circuito inferior. Aliás, podemos dizer que a reestruturação econômica desse território vem sendo desencadeada, desde a segunda metade do século XX, principalmente por meio das atividades desse subsistema.

Outro aspecto de ordem econômica que ocasiona a expansão do circuito inferior é a produção da pobreza estrutural. Nos dias atuais, a pobreza é planejada pelos agentes hegemônicos do capital e tornada global, caracterizando todos os países do mundo. Do mesmo modo, ela é produzida de maneira estrutural, isto é, apresentando-se como uma situação duradoura e como uma estratégia importante de acumulação ampliada de capital pela economia hegemônica, via banalização, entre os pobres, do consumo de objetos relacionados com as variáveis-chave do período. Com essa banalização, cresce o número de atividades do circuito inferior que usam ou comercializam objetos técnicos modernos, como também aumenta a quantidade de agentes da economia não hegemônica que consomem no circuito superior, alimentando-o com os lucros que obtêm no circuito inferior. Assim, a pobreza, podendo ser entendida como sinônimo de circuito inferior, é expandida e tornada cada vez mais estrutural à medida que o consumo moderno é amplificado.

Nessa perspectiva, consideramos que a própria natureza do circuito inferior, na atualidade, também contribui para sua expansão. Característica tradicional e atual do circuito inferior é a fragmentação extrema das tarefas em suas atividades, fato que aumenta as ocupações e a importância desse subsistema para a geração de renda para inúmeros trabalhadores. Já como características da atualidade desse circuito importantes para sua expansão apontamos a combinação de diferentes atividades num mesmo estabelecimento comercial e a incorporação, em sua organização, de variáveis-chave modernas. Essa combinação de diferentes atividades é fator que pode diminuir os riscos de prejuízo e aumentar os rendimentos na economia não hegemônica, ocasionando também a amplificação da circulação de mercadorias e, desse modo, da divisão do trabalho nesse circuito e elevando as ocupações. Do mesmo modo, a incorporação de variáveis do período no subsistema inferior, como instrumentos de trabalho ou como objetos de consumo ou comercialização, impulsiona a realização de novas tarefas na economia não hegemônica bem como o desenvolvimento de novas atividades, alargando ainda mais a divisão do trabalho.

Outrossim, não podemos desconsiderar que a própria forma como a urbanização vem ocorrendo no eixo rodoviário Natal-Caicó contribui para a expansão do circuito inferior. As cidades vêm crescendo de maneira intensa e não ocorre, paralelamente, a dinamização veemente de uma economia geradora de empregos em quantidade e com qualidade. Destarte, a elevação do número de atividades e de ocupações da economia não hegemônica apresenta-se como fato importante para o crescimento urbano, mas esse crescimento também é condição para aquela expansão, já que quanto maiores são as cidades mais complexo 
é seu mercado de trabalho, possibilitando que mais atividades, e novas, sejam desencadeadas pelos pobres. Assim, a intensa urbanização do eixo Natal-Caicó se constitui em fato e fator da expansão do circuito inferior.

Nesses termos, parece-nos evidente que há uma simetria entre os processos de modernização econômica e intensificação da urbanização do território e de precarização das relações e do mercado de trabalho. Isso porque o processo de urbanização caminha junto com a modernização econômica do território, decorrendo de ações estatais e de agentes hegemônicos do mercado que privilegiam interesses de determinados espaços, circuitos econômicos, classes e agentes sociais. Assim, ele intensifica a seletividade espacial e ocasiona a elevação da produtividade e a diminuição dos rendimentos do trabalho, bem como enfraquece os direitos trabalhistas e substitui empregos de qualidade por empregos precários ou ocupações. Precarizam-se as relações de trabalho, que, cada vez mais, são alicerçadas em acordos temporários e na diminuição das garantias trabalhistas.

Ao privilegiar os interesses econômicos hegemônicos, inclusive os internacionais, que repatriam os ganhos obtidos e pouco ou nada contribuem positivamente para a economia nacional em que se instalam, a modernização econômica do território dos países subdesenvolvidos também se alicerça na introdução de tecnologias intensivas em capital nas atividades econômicas, sobretudo do circuito superior da economia urbana, ação que não tem um efeito benéfico na vinculação empregatícia de mão de obra, contribuindo para o crescimento do desemprego, do emprego precário e das ocupações sem segurança alguma para os trabalhadores (SANTOS, 1978). Sendo assim, precariza-se também o mercado de trabalho, à medida que a maioria dos trabalhadores só consegue desenvolver alguma tarefa e, desse modo, usar o território por suas próprias forças e espontaneidades, e não por empregos criados pelos agentes hegemônicos do mercado ou por ações estatais.

Destarte, o crescimento das cidades dos países subdesenvolvidos caminha de braços dados com a precarização do trabalho, numa situação em que o circuito superior da economia urbana provoca aumento de consumos e escassez de empregos, tornando-se mais e mais, dominante nas relações com o circuito inferior e determinante no comando da dinâmica do território. Nessa situação, coexistem a modernização das atividades econômicas desenvolvidas e a expansão da pobreza; o crescimento da economia e a diminuição dos rendimentos dos trabalhadores, a expansão do desemprego, do emprego precário e das ocupações. Refletindo sobre essa situação na escala das metrópoles, Santos (1990) fala em "involução metropolitana". No entanto, a simetria entre modernização econômica e precarização do trabalho e, por que não dizer, das condições de vida não se limita às metrópoles, caracterizando todo o processo de urbanização, tanto no 
âmbito das metrópoles e das cidades grandes ou de destaque regional quanto no das cidades locais. Assim, acreditamos que, hoje, seria mais pertinente falar em "involução urbana".

A simetria de processos sublinhada nos remete para uma importante questão: a de que a precarização do trabalho vem ocorrendo num contexto de crescimento econômico, e não de estagnação, ao contrário do que afirmam no Brasil autoridades políticas e a mídia, representantes da elite, com o escopo da defesa, a todo custo, do progresso econômico. No eixo rodoviário Natal-Caicó, por exemplo, o PIB dos municípios que o compõem cresceu, de maneira veemente, entre 2000 e 2010 (IBGE/SIDRA, 2014), apesar de a dinâmica territorial desse eixo ser predominantemente caracterizada por atividades do circuito inferior, que, em sua maioria, mais ocupam do que empregam trabalhadores, remunerando-os com o mínimo possível, até porque o lucro obtido com o desenvolvimento dessas atividades não é elevado.

Assim sendo, no eixo rodoviário Natal-Caicó, as cidades e a economia crescem alicerçadas, sobretudo, em atividades econômicas mantenedoras da pobreza estrutural produzida pela modernização do território, situação essa característica do processo de precarização do trabalho. Como resposta sistêmica a essa situação, tem-se a segmentação da economia urbana, com o subsistema inferior cada vez mais dependente do superior, assim como mais permanente e receptor de trabalhadores diante da precarização das relações de trabalho e do desemprego, hoje, duradouro.

\section{REFERÊNCIAS}

ANTUNES, R. A era da informatização e a época da informalização: riqueza e miséria do trabalho no Brasil. In: Riqueza e miséria do trabalho no Brasil. São Paulo: Boitempo, 2006. p. 15-35.

ARAÚJO, M. F. Planejamento territorial do Rio Grande do Norte: as desigualdades socioespaciais em ação. 2013. Dissertação (Mestrado em Geografia Humana) - Universidade de São Paulo, São Paulo.

ARAÚJO, T. B. Seridó: uma região viável. Revista Caicó em foco, Caicó, ano 1, n. 1, p. 6-7, jul. 2000.

ARMSTRONG, W. ; McGEE, T. G. Revolutionary change and the third world city: a theory of urban involution. Civilisations, 18 (3), 1968.

\footnotetext{
${ }^{6}$ Outrora, Armstrong e McGee (1968) explicitaram a noção de "involução urbana", para tratar do aumento concomitante do número de pobres e de determinadas atividades econômicas no meio urbano, em consequência da "ruralização da cidade", isto é, da intensa migração da população do campo para a cidade.

Anos mais tarde, num outro contexto espaço-temporal e com outro sentido teórico-metodológico, Santos (1989, 1990) propôs a noção de involução metropolitana, que diz respeito ao fato de o crescimento regional apresentar-se como mais importante que o da metrópole e ao de o crescimento da área metropolitana ser calcado, sobretudo, na expansão da pobreza, fazendo com que haja uma tendência a melhor qualidade de vida nas cidades do interior, em decorrência da modernização, que abrange também essas cidades. Para nós, considerando as consequências da modernização econômica sobre o mundo do trabalho, as quais abrangem a totalidade da dinâmica territorial urbana dos países subdesenvolvidos, é mais pertinente falar em "involução urbana”, já que a precarização do trabalho e das condições de vida da maioria dos trabalhadores não é particularidade das metrópoles. Entretanto, fica explícito que usamos a noção de involução urbana diferentemente do modo como Armstrong e McGee (1968) fizeram, porque não privilegiamos a "ruralização da cidade", mas, sim, a "precarização do trabalho" em todos os centros urbanos. Além disso, considerando a urbanização do território potiguar, frisamos novamente que esse processo ocorre, em sua totalidade, veementemente marcado pela expansão do circuito inferior. Portanto, o crescimento da pobreza pode até ser mais acentuado na grande cidade e em cidades próximas dela, mas não se limita a essa escala. É por isso também que preferimos falar em involução urbana.
} 
DURKHEIM. E. Da divisão do trabalho social. Tradução de Eduardo Brandão. São Paulo: Martins Fontes, [1930] 1999.

FEDERAÇÃO DAS INDÚSTRIAS DO ESTADO DO RIO GRANDE DO NORTE (FIERN). Dados estatísticos: comércio exterior, 2014. Disponível em: <http://www.fiern.org.br/index.php/centro-internacional-de-negocios/dados-estatisticos-comercio-exterior $>$. Acesso em: 18 mar. 2015.

GOMES, C. Formação sócio-espacial e dinâmicas urbano-regionais no Rio Grande do Norte: o lugar da Região Metropolitana de Natal. Urbe, Revista Brasileira de Gestão Urbana, Curitiba, v. 1, n. 2, p. 151-161, jul./dez. 2009.

INSTITUTO BRASILEIRO DE GEOGRAFIA E ESTATÍSTICA (IBGE). Sistema IBGE de recuperação automática (SIDRA). Disponível em: <http://www.sidra.ibge.gov.br/>. Acesso em: 11 mar. 2014.

INSTITUTO NACIONAL DE COLONIZAÇÃO E REFORMA AGRÁRIA (INCRA). Atlas fundiário brasileiro, 2014. Disponível em: $<$ http://www.incra.gov.br/servicos/pu blicacoes/outras-publicacoes/file/760-atlas-fundiario-brasileiro>. Acesso em: 24 de julho de 2016.

MONTEIRO, D. M. Terra e trabalho na história: estudos sobre o Rio Grande do Norte. Natal: EDUFRN, 2008.

MORAIS, I. R. D. Seridó norte-rio-grandense: reestruturação e planejamento regional. In: XI ENCONTRO NACIONAL DA ASSOCIAÇÃO NACIONAL DE PÓS-GRADUAÇÃO E PESQUISA EM PLANEJAMENTO URBANO E REGIONAL. Anais... Salvador: UFBA/ANPUR, 2005a.

MORAIS, I. R. D. Seridó norte-rio-grandense: uma geografia da resistência. Caicó: Edição do autor, 2005b.

MINISTÉRIO DO TRABALHO E EMPREGO (MTE). Relação Anual de Informações Sociais (RAIS). Disponível em: <http://pdet.mte.gov.br/>. Acesso em: 08 de maio de 2014.

SALVADOR, D. S. C. O. Das farinhadas à produção para o mercado: a dinâmica da atividade mandioqueira no território do Agreste Potiguar. Natal: EDUFRN, 2013.

SANTOS, M. O espaço dividido: os dois circuitos da economia urbana dos países subdesenvolvidos. Rio de Janeiro: Livraria Ed. Francisco Alves, 1978.

SANTOS, M. Meio técnico-científico e urbanização: tendências e perspectivas. In: SEMINÁRIO BRASIL SÉCULO XXI, Anais... Campinas: UNICAMP, 1989.

SANTOS, M. Involução metropolitana e economia segmentada: o caso de São Paulo. In: RIBEIRO, A. C. T. ; MACHADO, D. B. P. (org.) Metropolização e rede urbana: perspectivas dos anos 90. Rio de Janeiro: IPPUR/UFRJ, 1990. p. 79-113.

SANTOS, M. A natureza do espaço: técnica e tempo, razão e emoção. São Paulo: Editora da Universidade de São Paulo, [1996] 2008. SECRETARIA DE ESTADO DO PLANEJAMENTO E DAS FINANÇAS (SEPLAN). Perfil do Rio Grande do Norte. Disponível em: <www.seplan.rn.gov.br/arquivos/dow nload/PERFI L\%20DO\%20RN.pdf>. Acesso em: 07 dez. 2014.

SOUZA, A. V. Emprego no Nordeste: o papel da integração regional. Recife: Fundação Joaquim Nabuco, Editora Massangana, 2000. 